\title{
KONSEP PERENCANAAN KEPERAWATAN DALAM ASUHAN KEPERAWATAN
}

\author{
FLORENCE ANGELINE NAINGGOLAN \\ Florenceangeline123@gmail.com
}

\section{Latar Belakang}

Asuhan keperawatan adalah faktor penting dalam kelangsungan hidup pasien dan aspek-aspek pemeliharaan, rehabilitatif dan prefentif perawatan kesehatannya.

Menurut Shore, untuk sampai pada hal ini, profesi keperawatan telah mengidentifkasi proses pemecahan masalah yang "menggabungkan elemen yang paling diinginkan dari seni keperawatan dengan elemen yang paling relevan dari sistem teori, dengan menggunakan metode ilmiah".

Proses keperawatan ini diperkenalkan pada tahun 1950-an sebagai proses yang terdiri atas tiga tahap : Pengkajian, perencanaan dan evaluasi yang didasarkan pada metode ilmiah pengamatan, pengukuran, pengumpulan data dan penganalisaan temuan.

Kajian selama bertahun-tahun, penggunaan dan perbaikan telah mengarahkan perawat pada pengembangan proses keperawatan menjadi lima langkah yang konkret (pengkajian, identifikasi masalah, perencanaan, implementasi dan evaluasi) yang memberikan metode efisien tentang pengorganisasian proses berfikir untuk pembuatan keputusan klinis.

Keperawatan adalah salah satu profesi pelaku pemberi pelayanan kesehatan, memiliki peranan penting dalam menentukan keberhasilan kesehatan secara keseluruhan. Pelayanan keperawatan merupakan pelayanan profesional sebagai bagian integral dari pelayanan kesehatan yang didasarkan ilmu dan kiat keperawatan (Nursalam, 2008). Tenaga perawat mempunyai kedudukan penting dalam menghasilkan kualitas pelayanan kesehatan dirumah sakit, karena pelayanan yang di berikannya berdasarkan pendekatan bio-psiko-sosial-spiritual merupakan pelayanan yang unik dan dilaksanakan selama 24 jam dan berkesinambungan, hal ini merupakan kelebihan tersendiri dibanding profesi kesehatan lainnya (DepKes RI, 2005).

Mutu asuhan keperawatan sangat dipengaruhi oleh kualitas pelayanan kesehatan dan bahkan 
sering menjadi salah satu faktor penentu citra institusi palayanan di mata masyarakat. Untuk menilai kualitas pelayanan keperawatan diperlukan adanya standar praktik keperawatan yang merupakan pedoman bagi perawat dalam melaksanakan asuhan keperawatan yang diwujudkan dalam bentuk proses keperawatan baik dari pengkajian sampai evaluasi (Nursalam, 2008).

\section{Metode}

Setiap organisasi mempunyai metode tersendiri atau format standar untuk dokumentasi keperawatan dalam catatan khusus.Pencatatan telah di pandang sebagai riwayat sekunder untuk perawatatan pasien. Sistem pendokumentasian yang digunakan harus mengomunikasikan status pasien, pemberian perawatan spesifik, dan respons pasien terhadap perawatan.

Metode kualitatif digunakan dengan mengumpulkan data untuk di analisis yang berfokus pada model dalam asuhan keperawatan dan konsep perencanaan keperawatan.

\section{Hasil}

Persepsi perawat juga memberikan pengaruh bahwa dengan persepsi negative tentu akan membuat asuhan yang akan diberikan perawat akan kurang berhasil.

Perawat perlu meyakinkan dirinya terhdaap tindakan yang akan dilakukan untuk memperoleh hasil yang baik.

Ini akan bermanfaat untuk memeberikan pelayanan yang baik dan tepat pada pasien. Proses keperawatan mengandung unsur-unsur yang bermanfaat bagi perawat dan klien. Perawat dan klien membutuhkan proses asuhan keperawatan, merencanakan, melaksanakan, dan menilai hasil dari asuhan keperawatan.

Semua itu memerlukan pendokumentasian sehingga perawat mendapatkan data klien dengan sistematis.

Perawat bertanggung jawab dan bertanggung gugat dalam pencatatan tindakan keperawatan. Tanpa dokumentasi yang benar dan jelas, kegiatan pelayanan keperawatan yang telah dilaksanakan oleh seorang perawat tidak dapat dipertanggungjawabkan dalam upaya peningkatan mutu pelayanan keperawatan dan perbaikan status kesehatan klien.

Persepsi perawat juga memberikan pengaruh bahwa dengan persepsi negative tentu akan membuat asuhan yanga akan diberikan perawat akan kurang berhasil.

Perawat perlu meyakinkan dirinya terhdaap tindakan yang akan dilakukan untuk memperoleh hasil yang baik. Ini akan bermanfaat untuk memeberikan pelayanan yang baik dan tepat pada pasien.

Perencanaan keperawatan adalah bagian dari fase pengorganisasian dalam proses keperawatan 
sebagai pedoman untuk mengarahkan tindakan keperawatan dalam usaha membantu, meringankan, memecahkan masalah atau untuk memenuhi kebutuhan pasien (Setiadi, 2012).

\section{Pembahasan}

Perencanaan keperawatan yaitu intervensi keperawatan merupakan bagian dariproses keperawatan yaitu tahap ketiga.

Setelah mengetahui diagnose keperawatan yang tepat untuk pasien, selanjutnya perawat menentukan dan memepersiapkan perencanaan keperawatan untuk diiimplementasikan ketika memberi asuhan keperawatan.

Perencanaan keperawatan yang dipersipakan oleh perawat tentunya harus berhubungan dengan kondisi pasien berdasarkan pengkajian dan diagnose keperawatan.

Perenacanaan keperawatan sangat diperlukan dalam pemberian asuhan keperawatan.

Ini dikarenakan dalam setiap tindakan yang akan dilakukan perawat sudah menyusun rencana keperawatan terlebih dahulu agar pada saat implementasi tidak salah.

Perawat perlu menyiapkan hal ini untuk memberikan pelayanan yang baik bagi pasien. keperawatan perawat pelaksana sudah sangat baik dalam melakukan pengumpulan data, pengelompokan data, menganalisis data guna merumuskan diagnosis keperawatan. Hal tersebut dikarenakan perawat ruangan sangat paham mengenai pengkajian keperawatan maupun prosesnya.

Rencana keperawatan merupakan metode komunikasi tentang asuhan keperawatan kepada klien. Menurut asumsi peneliti perawat telah melakukan perencanaan keperawatan, menentukan tujuan, dan telah memilih intervensi yang baik untuk mencapai tujuan keperawatan.

Rencana tindakan keperawatan untuk membantu pasien dalam mencapai tujuan dankriteria hasil yang diharapkan. Beberapa tipe rencana tindakan keperawatan yaitu:

a. Observasi, disini perawat akan mengobservasi terhadap kemajuan pasien dengan memantau perubahan pasien setelah diberikan intervensi. Diharapakan sesuai dengan tujuan dan kriteria yang diharapkan.

b. Terapeutik, tindakan yang dilakukan perawat untuk mengurangi, mencegah masalah. Perawat harus bisa dipilih tindakan yang paling sesuai dengan keadaan pasien.

c. Penyuluhan, tindakan ini berupa pendidikan kesehatan ini berguna untuk partisipasi pasien terhadap masalah kesehatan yang dialami pasien. Pasien bertanggungjawab untuk perawatan dini pasien.

Tindakan pencegahan lebih baik daripada pengobatan. Dalam penyuluhan ini perawat juga mnenyesuaikan materi yang akan diberikan dengan kondisi pasien. 
d. Kolaboratif, rencana kolaboratif disesuaikan dengan masalah yang terjadi. Masalah yang berhubungan dengan perubahan fungsi tubuh ataupun patologis memerlukan kolaboratif dengan tenaga kesehatan lainnya. Perawat melindungi pasien dari hal yang dapat merugikan dan memberikan saran yang bersifat konstruktif yang dapat menunjang kesembuhan pasien.

Langkah - langkah perencanaan keperawatan adalah sebagai berikut:

a) Menentukan prioritas masalah.

Prioritas keperawatan adalah penyusunan diagnose keperawatan atau masalah pasien dengan menggunakan tingkat kedaruratan atau kepentingan untuk memperoleh tahapan intervensi keperawatan yang dibutuhkan. Saat menentukan prioritas diagnosa keperawatan digunakan standar prioritas kebutuhan dari Maslow, sebagai berikut :

Prioritas 1 : masalah yang berhubungan dengan kebutuhan fisiologis seperti respirasi, sirkulasi, nutrisi, hidrasi, eliminasi, suhu dan kesenjangan fisik.

Prioritas 2 : masalah yang berpengaruh pada keselamatan dan keamanan.

Prioritas 3 : masalah yang berpengaruh terhadap cinta dan rasa memiliki.

Prioritas 4 : masalah yang berpengaruh pada rasa harga diri.

Prioritas 5 : masalah yang berpengaruh pada kemampuan mencapai sasaran pribadi atau aktualisasi diri.

b) Menuliskan tujuan dan kriteria hasil.

Tujuan perawatan adalah hasil yang diinginkan dari asuhan keperawatan yang diharapkan dapat dicapai bersama pasien serta direncanakan untuk mengurangi masalah yang telah diidentifikasi dalam diagnosis keperawatan . Saat merumuskan tujuan, yaitu :

(1) Tujuan dinyatakan dengan istilah hasil yang ingin dicapai, bukan tindakan keperawatannya.

(2) Tujuan keperawatan harus menggambarkan perilaku pasien yang dapat diamati dan diukur.

(3) Tujuan harus realistis, mencerminkan kemampuan dan keterlibatan pasien.

(4) Setiap tujuan berdasarkan dari satu diagnosis keperawatan.

Kriteria hasil mempunyai ciri-ciri menurut Dermawan (2012) yaitu setiap kriteria hasil berhubungan dengan tujuan yang telah ditetapkan, hasil yang ditetapkan dalam kriteria hasil, memungkinkan untuk dicapai, setiap kriteria hasil adalah pernyataan satu hal yang spesifik, kriteria harus sekonkrit mungkin untuk memudahkan pengukuran, kriteria cukup besar atau dapat 
diukur, kriteria menggunakan kata-kata positif bukan menggunakan kata negatif. Pedoman penulisan kriteria hasil menurut Setiadi (2012) adalah berfokus pada pasien, singkat dan jelas, dapat diobservasi dan dapat diukur, ada batas waktu, ditentukan oleh perawat dan pasien.

Menurut Ilyas (2002) bahwa, pendidikan menggambarkan ketrampilan dan kemampuan idividu. Selain itu, melalui pendidikan, seseorang dapat meningkatkan kematangan intelektualnya, sehingga dapat membuat keputusan dalam bertindak.

Hasil penelitian ini juga menggambarkan bahwa perawat pelaksana telah melakukan asuhan keperawatan pada tahap perencanaan/intervensi keperawatan dimana tujuannya berpusat pada pasien, dan hasil yang diperkirakan ditentukan dan intervensi keperawatan dipilih untuk mencapai tujuan (Potter \& Perry, 2005, p.180)

\section{Penutup}

Perencanaan keperawatan yang dipersiapkan oleh perawat harus berhubungan dengan kondisi pasien berdasarkan pengkajian dan diagnose keperawatan. Perencanaan keperawatan menjadi dasar perawat dalam mengimplementasikan tindakan yang akan dilakukan. Beberapa hal yang perlu diperhatikan dalam perenacanan keperawatan seperti menentukan prioritas masalah, menentukan tujuan dan kriteria hasil yang diharapkan, merumuskan rencana tindakan keperawatan dan rasional rencana tindakan keperawatan. Perencanaan keperawatan merupak bagian dari proses keperawatan yang bermanfaat dalam pelayanan dan asuhan yang akan diberikan perawat kepada pasien.

\section{Referensi}

Asmadi, 2008. Konsep Dasar Keperawatan. Jakarta. EGC

Achmadi, L. D. (2015, Agustus). Gambaran Tingkat Pengetahuan Perawat dalam Penerapan Standar Asuhan Keperawatan di Ruang Rawat Inap Interna RSUP Datoe Bhinangkang. e-journal Keperawatan, 3.

Budiono, \& Parman, S. (2015). Konsep Dasar Keperawatan. Jakarta: Bumi Medika.

Butar-Butar, J., \& Simamora, R. H. (2016). Hubungan Mutu Pelayanan Keperawatan dengan Tingkat Kepuasan Pasien Rawat Inap di RSUD Pandan Kabupaten Tapanuli Tengah. Jurnal Ners Indonesia, 6(1), 50-63

Carpenito, \& Juall, L. (1999). Rencana Asuhan \& Dokumentasi Keperawatan. (Y. Asih, Ed.) Jakarta: EGC. 
Cristensen, Paula J. 2009. Proses Keperawatan Aplikasi Model Konseptual Edisi 4. Jakarta : EGC.

Efendi,N.F.(2015). Pendidikan dalam keperawatan. Surabaya: Salemba Medika

Nursalam 2011, Konsep dan penerapan metodologi penelitian ilmu keperawatan: Medika, Jakarta

Purnamasari, L. D., \& Ropyanto, C. B. (2012). Evaluasi Pelaksanaan Perencanaan Pulang. Jurnal Keperawatan Diponegoro, 1, 213-218.

Saputra, H. (2014). Hubungan Penerapan Asuhan Keperawatan dengan Pemenuhan Kebutuhan Spiritual Pasien di Ruang Rawat Inap Kelas III RS PKU Muhammadiyah Yogyakarta. 1-19.

Simamora, R. H. (2005). Hubungan Persepsi Perawat Pelaksana Terhadap Penerapan Fungsi Pengorganisasian Yang Dilakukan Oleh Kepala Ruangan Dengan Kinerjanya Diruang Rawat Inap RSUD Koja Jakarta Utara (Doctoral dissertation, Tesis FIK UI, Tidak dipublikasikan).

Wirdah, H., \& Yusuf, M. (2016). Penerapan Asuhan Keperawatan oleh PerawatPelaksana di Rumah Sakit Banda Aceh. PSIK Unsyiah, 1(1), 1-6. 